John Carroll University

Carroll Collected

2017

\title{
Internal Renewal and Dissent in the Early Christian World
}

Sheila E. McGinn

John Carroll University, smcginn@jcu.edu

Follow this and additional works at: https://collected.jcu.edu/fac_bib_2017

Part of the Christianity Commons

\section{Recommended Citation}

McGinn, Sheila E., "Internal Renewal and Dissent in the Early Christian World" (2017). 2017 Faculty Bibliography. 13.

https://collected.jcu.edu/fac_bib_2017/13

This Book Chapter is brought to you for free and open access by the Faculty Bibliographies Community Homepage at Carroll Collected. It has been accepted for inclusion in 2017 Faculty Bibliography by an authorized administrator of Carroll Collected. For more information, please contact connell@jcu.edu. 


\section{THE EARLY CHRISTIAN WORLD}

SECOND EDITION

Edited by Philip F. Esler 
This book is dedicated to the memory

$$
\text { of Patrick Bernard Carey }
$$

(16 December 1946-18 July 2016) 


\title{
INTERNAL RENEWAL AND DISSENT IN THE EARLY CHRISTIAN WORLD
}

\author{
Sheila E. McGinn
}

Perhaps one of the most significant debates of the twentieth and twenty-first centuries among scholars of early Christianity is the extent to which it is appropriate to speak of 'orthodoxy' and 'heresy' before the Council of Nicea (325 CE). The rise of historical criticism and its application to the development of doctrine shattered scholars' former straightforward assumption of the canon of Vincent of Lerins - that orthodoxy is what was believed by everyone, everywhere, at every time. Before many had come to terms with the evidence calling this assumption into question, a second and more significant challenge was raised by the German scholar Walter Bauer. In his Rechtgläubigkeit und Ketzerei im ältesten Christentum (Orthodoxy and Heresy in Earliest Christianity, 1934), Bauer called into question even the more modest assumption retained by late nineteenthand early twentieth-century scholars that orthodoxy was the common faith from which heretics then diverged. On the contrary, Bauer argued, heresy came first and then orthodoxy.

The working assumption of the priority of orthodoxy, however, was not easily unseated. Its durability is illustrated by the fact that it took an entire generation before Bauer's challenge really gained much attention. Not until the mid 1960s did Bauer's work reach international recognition with its second German edition (1964), and then its English translation (1971). Prior to this, most scholars seem to have ignored it in the hope that its challenge would go away.

Such a substantial critique of the former scholarly approach could not be brushed aside forever. With the rise of 'engaged' scholarship in the seventies (for example, in liberation theology and feminist hermeneutics), many began to press the question of what social, economic, and political factors may have influenced the doctrinal controversies of the first Christian centuries. Ecclesiastical decisions privileging certain doctrines over others were no longer viewed in a theological vacuum, but came to be seen in the context of wider social processes. All this transpired just as Bauer's work was finding a wider audience.

The title of this essay illustrates how far the pendulum has swung. Less than a generation ago, this section of a volume on the early Christian world would have been entitled 'Heresy and heresies. Now the discussion is set in the framework of 'Internal renewal and dissent in the early Christian world.' Individual movements still are given their traditional names-Gnosticism, Montanism, Donatism, and Arianism-although without attempting to prejudge the question of their propriety, which currently itself is a matter of considerable debate, as the subsequent four essays in this volume will show. On the other hand, Darrell Bock recently argued (2006) against the notion that Gnostic 
gospels represent an original Christianity that was later suppressed. The positive reception for this gospels represent an original Christianity that was later suppressed. The positive recen to redefining early
book suggests a continuing reticence on the part of many scholars when it comes to

Christian 'boundaries'

While 'renewal' (a revival of a previously accepted practice) is a less controversial subject, some scholars of early Christianity (traditionally known as 'patristics') bemoan the recent interest in heresy. scholars of early Cha from privileging conciliar decisions and statements of the "Fathers of the The scholarly shift away fom application of historicalChurch' is seen as bad enough, but at least 'it is undew developed, they claim, is not critical methods to studies of this early literature. However, what has developed, they claim, is no an even-handed historical analysis, but rather the privileging of the heretics (c.g., Henry 1982: 124).

Given the significance of the present debate and the breadth of evidence being adduced, attempting to summarize the sea of current thinking feels somewhat like walking on water. Nevertheless, a ing to summarize the sea of current thinking fee remembers that such generalizations will always have few broad strokes can be drawn,
their exceptions in specific cases.

\section{Insiders and outsiders}

'Heretics,' according to the traditional definition, are 'outsiders,' those who have gone beyond the 'Heretics,' according to the traditional definitin, are 'outsdes, 'hat 'orthodoxy' is what heen boundaries of the true faith. The Vincentian canon stipulan believed in the church by everyone, in every place, throughout tine. Thus, if one adhers to some other kind of belief, by definition that places the person 'outside' the church. According to this view, the contrary to

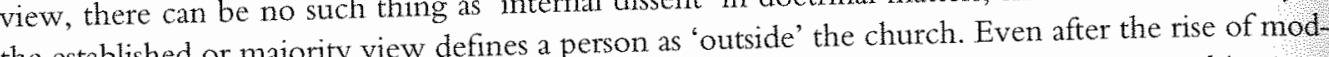
the established or majorits ern historical methods and the advent of a cilical appout the nineteenth and twentieth centuries remained unchallenged for quite some time. Throughout the nineteen and twentieth centuries Church historians often simply repeated the sentence of their uncritical forebears when it came to determining 'orthodoxy' of insiders and the 'heterodoxy' or 'heresy' of 'outsiders.' 1881 with One of the first signs that this uncritical dike was beginning to leak cantanism). Bonwetsc G. Nathanael Bonwetsch's Die Geschichte des Montanismil (The been a heretic, and he attributed noted a shift in scholarly assessment of whether Tertullan had been a hent was herical or not this shift as sparking a reassessment of whether the Montanist novent The question itself attested to an increasing awaren

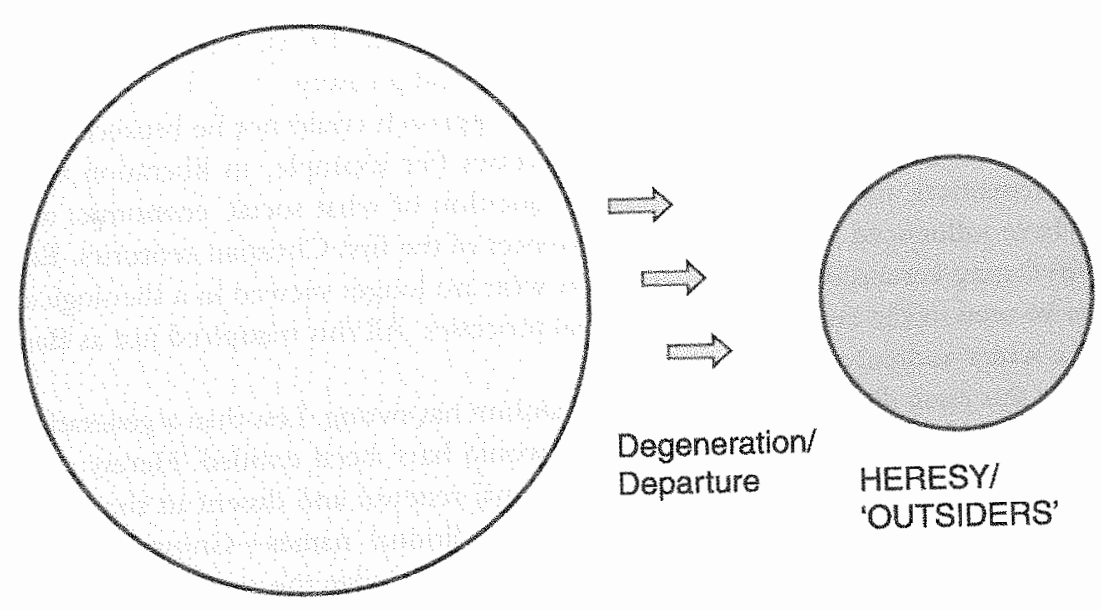

ORTHODOXY/INSIDERS'

Fisure 41.1 Orthodoxy and heresy in early Christianity as constituted by insiders and outsiders movements that were doctrinally at variance with 'the great church' as well as ones that evidenced no such doctrinal variations, but rather showed variations in ecclesiastical practice or discipline. Hence, scholars began to distinguish between 'heresy' as divergences from the belief system of 'the great church' and 'schism' as divergences in practice or discipline. Of course, at the same time, although they were often not cognizant of the significance of this language shift, they began to develop a new mapping of 'insiders' and 'outsiders' in the history of early Christianity. And with this boundary shiff began a new paradigm shift in the historical approach to opposing views in early Christianity.

The recognition of 'schism' as a distinct category from 'heresy' blurred the once clear boundary between 'insiders' and 'outsiders.' In the past, it was assumed that all those who were 'insiders' must have believed the same doctrines, worshiped in the same ways, followed the same disciplinary practices, and accepted the same leadership models. Any recognizable variation on these points was taken as a sign of being an 'outsider' to the great church - a heretic. Now it was argued that doctrine alone provided the dividing line between the 'insiders' versus the 'outsiders.' One potentially could find a set of believers who engaged in different rituals, followed different disciplinary practices and also lived under a totally different ecclesiastical leadership structure than the great church, and yet evaluate them as 'insiders' - as long as there was no evidence of doctrinal disagreement. Thus was born the notion of internal 'dissent' or renewal as an historical reality for early Christianity.

It is perhaps not coincidental that this paradigm shift in evaluating early Christianity occurred toward the middle of the twentieth century, when there was a concomitant shift taking place in the relationships among major Christian denominations. The rise of the 'ecumenical' movement and of 'interfaith' dialogue among Catholics, Orthodox, Anglicans, and Lutherans, among others, shows the fruits of the ressourcement movement, where historians took a fresh look at Christian origins and what light the historical sources from the formative period might be able to provide for the life of the contemporary church. The pastoral effect of the historians' paradigm shift was the eventual recognition among different Christian groups that this is precisely what they were- different groups within Christianity, rather than one Christian Church assailed by many heretical groups.

The post-war period also evidenced a growing awareness of the social and political uses (and abuses) of religion. The manipulation of the German ecclesiastical structure by the Nazi powers was lamented as one of the more serious causes of the Holocaust. The devastating, immoral, social, and political effects of the branding of one group as 'heretics' and 'outsiders' could no longer be ignored. This gave church historians an added impetus to seek out the origins of such labels, as well as their social and political uses, and reassess their validity.

\section{Early Christian trajectories}

A watershed of this new discussion was the 1971 work of James M. Robinson and Helmut Koester Trajectories Through Early Christianity, where they laid out the evidence for early Christianity being a multiform reality, with differing characteristics dependent upon the geographical, social, and cultural location in which it was found. At almost the same time, Robert Wilken directly confronted the Vincentian canon in The Myth of Christian Beginnings (1971). These studies were followed almost immediately by a wave of discussions of diversity in the early church, and even in the New Testament itself, as in James Dunn's 1977 work, Unity and Diversity in the New Testament. Koester furthered the argument for the diversity of the early Christian movement in his two-volume New Testament introduction (1982), breaking one further barrier by including apocryphal writings contemporaneous to the New Testament materials. Within two decades, what was taken for granted in discussions of the New Testament texts was no longer their consistency, but rather their variety; the unity of their thought was what required an argument (see Reumann 1991 and Achtemeier 1987).

Perhaps the most significant feature thereby raised in the 'orthodoxy $\mathrm{v}$. heresy' discussions in the last quarter of the twentieth century has been the oft-repeated question of 'by whom are they considered heretics?' None of the extant literature of early Christianity claims the title heretic for its author; 


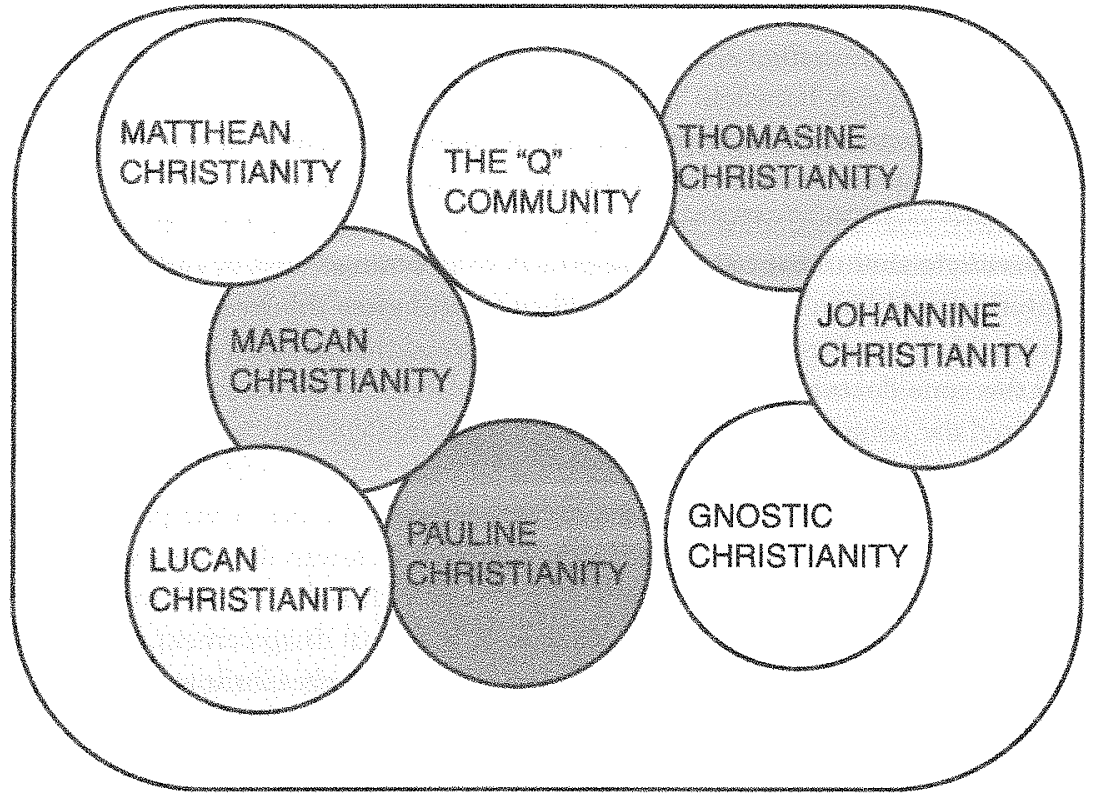

Figure 41.2 Christianities in the New Testament and related literature

on the contrary, each author views her/himself as teaching true doctrine. If a 'false doctrine, is in view, it is that taught by others who are stigmatized as 'outsiders' to the teacher's group. The dynamic of 'insiders' (those who know the truth) versus 'outsiders' (those who teach and believe falsely) has been previously noted. These categories remained unquestioned before the late nineteenth century Even when the categories began to be challenged, the 'insider' v. 'outsider' distinction remained inviolate; for decades afterwards, it was still taken by most scholars as descriptive of the historical situation rather than being viewed as prescriptive for the ancient audience. But eventually the sociological and political dimensions of this language were noticed, and scholars began to undertake a serious analysis of its significance.

The new 'theologies of liberation' both arose out of and expanded upon this social and political analysis. Sociologist George Zito summarizes the common view of liberation theologians, as well a of many contemporary historians of early Christianity, when he explains that the heretical status of an articulated opinion is determined by an institutional process of legitimation by the discourse within which a heresy is voiced (1983). 'Heresy' is a thought-world that threatens established power relations, whether ecclesiastical or political. In short, scholars must recognize that speech is contextual and perspectival; whether overtly or covertly, it both expresses and reinforces group boundaries. One can no longer speak simply of orthodoxy and heresy without defining whose orthodoxy or whose heresy. And the determination of which view will become orthodoxy is not only a theological process, but a social and political one as well.

Framing the discussion of theological trends or movements within early Christianity as a question of 'internal renewal and dissent' - rather than of 'orthodoxy versus heresy' - presumes this paradigm shift from the notion of a universal Christianity with uniformity of belief and practice to that of an ecumenical Christianity with some consistent patterns as well as distinctive features in every place where it was found. The boundaries between 'insider' and 'outsider' become very hazy indeed. If we suspect as prescriptive, rather than descriptive, the statements of ancient authors who charge another group with 'heresy,' then the only boundary guidelines that remain are those that are self-selected by the groups themselves. This shift of the burden of proof is one of the developments that troubles scholars such as Henry (1982). And unsettling it well may be, for it certainly has complicated the

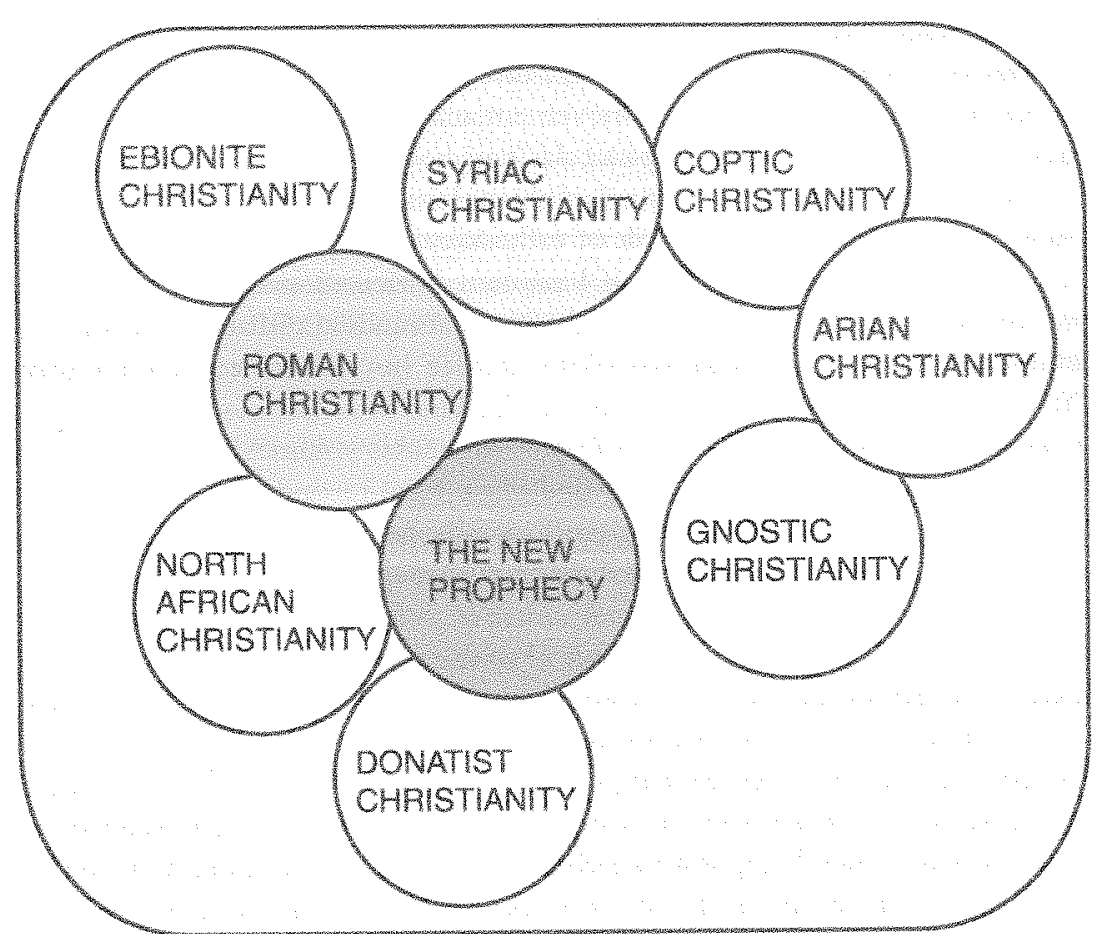

Figure 41.3 Christianities in the first four Roman centuries

issues. It has broadened the scope of early Christianity so much that most scholars today speak of 'early Christianities' rather than referring to a singular, univocal description of the movement.

In this context, the notion of 'internal renewal and dissent' comes to have two meanings. In the broadest sense, it simply refers to the pluralism that we find among these different trajectories of early Christianity due to their varied geographical, social, and cultural contexts-whether or not there actually seems to have been any overt historical conflict over these different developments of the Christian movement. In the second place, it refers to the actual differences of opinion that did indeed arise among various sectors of Christianity in its formative period.

\section{Re-visioning the past}

While the terms 'renewal' and 'dissent' may imply a prior standard to which one wants to return or from which one wishes to diverge, they need not be read that way. On the contrary, the scholarly consensus at this point seems to be that variety preceded the development of a universal standard among the early churches. Taking into account the gradual development of agreement on issues of doctrine and practice, what appears in retrospect as 'dissent' originated as one option among many, each of which over time rose or fell in popularity and persuasiveness. Only after one of these alternatives becomes the dominant view can we see the other alternatives as 'dissenting' (see Bauer 1972). Similarly, what in retrospect appears as an 'internal renewal' movement (e.g., the New Prophecy or churches, or dominant in one particular geographical region, and then later to have spread to other
sectors of the church. Each case must be decided on its own grounds.

The remainder of this chapter is devoted to four examples of how such alternative approache might change the way we envision the earliest history of Christianity. To attain a sense of how powerful 
this paradigm shift might be, I have taken examples from across the spectrum of the early Christian movement: a case of orthodoxy, a case of heresy, a case of schism and a true 'outsider' group.

The first example is from an 'orthodox' movement and leader, to see how our picture of orthodoxy changes if we re-contextualize this particular trajectory within it. Paul of Tarsus and Pauline Christianity (considered in detail in Chapter 7 of this volume) provide a perfect case study, because Paul's teaching often is seen as the hallmark of orthodoxy; indeed, Paul sometimes has been considered 'the founder of Christianity' itself. If Paulinism is viewed as one of the many choices in first-century Christianity, how does this change our understanding of Paul's teaching and practice? What if Paulinism is no longer the hallmark of the 'insider' but rather a version of Christianity that may have been 'outside' the mainstream?

The second example is Gnosticism (see Chapter 42 of this volume), a movement traditionally understood as a heresy. But what would we find if we tried to understand Gnosticism as simply one of the many alternatives available during the formative period of Christianity? What would the Christians labeled as Gnostics tell us about Christian faith and life if we viewed them as Christians rather than as 'Gnostics?'

Next, we will turn to Montanism (see Chapter 43 of this volume), a late second-century prophetic movement which its earliest opponents labeled a heresy, but which since has been understood as a schism. What difference does it make if we construe Montanism as a renewal movement within early Christianity, rather than a movement breaking away from early Christianity? Renewal means a revival of some lost practice and/or belief from the past. If Montanism really was a renewal movement, what was it that the Montanists saw being lost to early Christianity that needed to be recovered? Finally, Manichaeism represents the example of a true 'outsider' group, a distinctive religion in its own right, which provides competition for Christianity in the third century and beyond.

\section{Paul of Tarsus, the first dissident}

Antique historians and heresiologists (e.g., Irenaeus of Lyons, Eusebius of Caesarea) viewed Simon Magus as 'the first author of all heresy' (Eusebius, Historia Ecclesiastica 2.13.5; cf. Irenaeus, Adversus Haereses 1.23.1) but Gerd Lüdemann (1996) was among the first to challenge this view. Following up on a comment of Walter Bauer (1971: 236, n.83), Lüdemann named Paul of Tarsus as 'The only heretic of the earliest period' (1996: 61). What he meant to emphasize, of course, is that the notion of 'heresy' is perspectival and contextual. Furthermore, given Paul's context in the first decades of

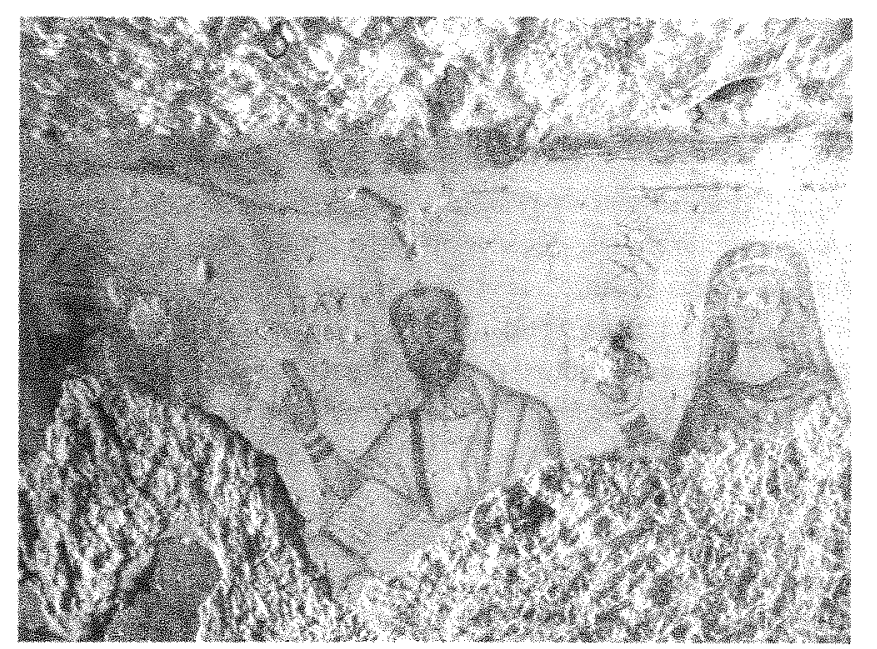

Figure 41.4 Paul, from a fourth-century fresco in a cave in Ephesus; Photo Sheila McGinn the Christian movement, his views were divergent from the 'mainstream' understanding of what it meant to be a follower of the Messiah Jesus-assuming that one defines the 'mainstream' from the viewpoint of the mother church of Christianity, the Jerusalem church.

Although we may demur from his label for Paul, Lüdemann's basic point is well taken. If we take into account the New Testament materials that pertain to Paul and his teachings, including Paul's own letters, it becomes clear that Paul is arguing for an alternative understanding of Christianity from what was dominant in the Jerusalem church of the 40 s and 50 s, and probably also in Rome as well. According to both Acts 15 and Galatians 2, the 'Council of Jerusalem' was convened at least in part to adjudicate between these two divergent presentations of the gospel. Acts 15:2 mentions that the reason for the meeting is 'dissension' between Paul and others. (Luke uses the term stasis, which can even mean 'revolt.') Clearly Paul believes that some Christians from Jerusalem are behind the 'Judaizing' troubles in Galatia, and he goes to great lengths to refute their position. In Galatians 2:11-14, Paul even mentions a later public confrontation with Peter in Antioch about the proper behavior in fellowship meetings, possibly indicating deep division between Paul on the one hand and Peter and James on the other (Esler 1998: 126-40). Whether Paul was successful among the Galatians, we do not know; but he seems never to have returned to Antioch after this incident with Peter, which suggests that Paul's view was not the winner in Syria. Neither does his apparent foreboding about his return to Jerusalem (in Rom. 15:30-32) bespeak a victory there.

We are left with a picture not of Paul as a spokesperson for the 'orthodox' or 'mainstream' view, but rather a marginalized Paul dissenting from the prevailing view, working from within-or perhaps along the fringes-for reform of an apparently well-established practice of having two ranks of converts, the first for men of Jewish origin and the second for women and Gentile men. This dissident Paul is castigated by many of his contemporaries for teaching an inadequate gospel and is even rejected for engaging in practices that are called idolatrous (e.g., Rev 2:14, 20; cf. 1 Corinthians 8)!

One hundred years later, this picture is dramatically changed (see, e.g. Justin Martyr, Dialogue with Trypho 19; 43; Tertullian, On Baptism 12:1; cf. Col 2:11-12). The gospel message was winning many more adherents among the Gentiles than the Jews, especially in regions like Roman Asia Minor and Egypt. No longer the minority voice, Paul's view on church practice has become the dominant one and the Jewish-Christian view has become the one marginalized. To achieve membership in the Christian movement, one must accept the faith of Christ and receive baptism; circumcision is no longer an issue. The question of male-female relations in the church is not so easily resolved, but Paul's argument for equal treatment of Jews and Gentile converts in the church has won the day. In fact, it is nearly a moot point given that the overwhelming majority of new Christians come from Gentile origins. Eventually, the hard-liners who want to retain a more Jewish identity as Christians, rather than labeling Paul, are themselves the ones who are labeled, and these 'Ebionites' gradually fade out of our historical picture.

Which is it to be, Paul as 'apostle to the Gentiles' or 'first among the heretics'? Was Paul of Tarsus an 'insider' or an 'outsider'? If we follow this new paradigm, then the answer must be 'both.' This is no mere equivocation, but rather a judgement imposed on us by the facts of the case. How we will use Paul's teachings in our time is a decision open to Christians of all stripes-laity, clerics, and theologians-but how to evaluate Paul in his own time is a historical judgement that must be faithful to the historical data. And, as discomfiting as it may be to us, the data do not agree. To many of his contemporaries, Paul was a dissident and troublemaker. Later believers saw him rather as a great teacher and visionary. They can both be 'right.' John Barclay (1995) has argued for the need to take the perspective of the observer into account in assessing how Paul (and other ancient Jews of questionable status) were regarded by their contemporaries.

For the most part, Paul's proponents were looking at the same features of Paul's theology as his detractors (e.g., the relationship between Torah and gospel; the circumcision question), but they evaluated these features differently because they came from different social and cultural contexts and, hence were interested in fostering different social relations. Uncovering the context of their evaluations has 
provided greater depth and breadth to the historical understanding of early Christianity. This same kind of 'contextualizing' approach also is underway in the study of such movements as Gnosticism, Montanism, Donatism, and Arianism - movements that once were known as 'heresies,' If the first dissident, Paul, can become a valuable resource for later believers, perhaps we may yet glean at least some small insights from these other dissenting groups as well. And we certainly can discover why these groups, who viewed themselves as Christians, believed that their particular understanding of Christianity was preferable to the other options of the time.

\section{What was it that the Gnostics knew?}

One of the earliest attempts to read dissenting voices from their own point of view was Elaine Pagels' study of the Gnostics. ${ }^{.}$Most well known for her study, The Gnostic Gospels (1982), she already had published two earlier studies of Gnostic exegesis of New Testament materials (1973, 1975). In The Gnostic Gospels, Pagels begins with the assertion that, in addition to its religious or theological content, 'the doctrine of bodily resurrection also serves an essential political function: it legitimizes the authority of certain men who claim to exercise exclusive leadership over the churches as the successors of the apostle Peter' (Pagels 1982: 38; original emphasis). This is not because the resurrection per se supports a particular leadership structure, but because the canonical traditions show the resurrection 1:21-22). The Gnostic gospels, on the other hand, promote a spiritualized understanding of Christ's resurrection that involves a 'direct, personal contact with the "living One"... [which] offers the ultimate criterion of truth, taking precedence over all second-hand testimony and all tradition' (Pagels 1982: 53). This notion of the resurrection, in giving pride of place to direct experience, thereby undercuts any possibility of developing an institutional structure of authority. The 'orthodox' view, on the other hand, centers on the validity of a past historical experience granted to certain of Jesus' earliest disciples; this necessarily makes those disciples and their experience an external criterion of truth, and thereby provides a solid ground on which to establish an institutional authority structure

This notion that there are socio-political dynamics involved in 'heresy-making' has by now become commonplace in early Christian studies. This does not mean, however, that the only dynamics involved in these early Christian debates were social and or political in nature. Pagels, for example, certainly overstated the case in attributing exclusively political motives to the proponents of the 'bodily resurrection' view versus the Gnostics. Her assumption that the claim of bodily resurrection necessarily supports an androcentric, patriarchal church structure cannot be supported in the face of the resurrection stories in the canonical gospels, all of which have women witnesses. Furthermore, the original ending of Mark's Gospel (16:1-8a) reports the empty tomb, which presumably indicates a belief in the bodily resurrection of Christ, yet the only witnesses are said to have 'said nothing to anyone' (16:8) and no post-resurrection appearances of Jesus are reported. Hence, it seems possible to hold to the 'orthodox' view of bodily resurrection without the political motives Pagels outlines. Still, if somewhat reductionistic in her conclusions, nevertheless Pagels' point is well taken that more than theolooy was at stake in these debates. Religions are human social organizations and, as such, they include human structures of power that are legitimated by the religious ideology. Scholars now recognize that early Christianity is not an exception but rather a clear example of this rule.

So, what did the Gnostics know? First of all, they recognized that repeating stories of postresurrection appearances of Jesus to certain individuals made those few individuals privileged witnesses to the resurrection event. Hence, telling such stories would be a means to proclaim the resurrection while also proclaiming the authority of those witnesses. Second, it seems reasonable to infer that the Gnostics recognized such a privileged status would generalize beyond authority concerning this one event to authority for interpreting the entire body of Jesus' teaching; no one else could experience the resurrected Lord the way these witnesses did, thus no one else could understand or teach the Lord's message as thoroughly as they did. Did they also envision that, third, this generalized authority would lead to a permanent, hierarchical rank for those witnesses - and, fourth, a similar authority for their 'successors' as well? This is less certain, although also possible - and they would have been right on all four points (see, e.g., Acts 2).

The Gnostics provided the following alternative to this scenario: (1) individuals become witnesses to the resurrection by means of a direct encounter with the Risen One; (2) thereby they become reliable witnesses both to the resurrection and to the entire body of Jesus' teaching; (3) although Pagels seems not to think so, it is possible that some individuals might even be granted a rank above others in the Gnostic church, due to the depth of their spiritual experience, their teaching ability, or some other distinguishing feature (cf. the importance of demonstrating charismatic gifts in 1 Corinthians 12-14). However, stage four in the preceding scenario could never take place; no one could 'succeed' someone in such an office, precisely because the office was based upon a direct experience of the foundational event of Christianity-the resurrection of the Lord. Each leader must begin with step one. And the leadership rank would not mean the same thing in the Gnostic church, for any member could become a leader; they all could expect to experience the resurrection in a direct and immediate way, regardless of teacher or training.

As with Paul, there are lessons to be learned from the Gnostics. The following are four that in fact have been taken up by different trajectories within Christianity, perhaps most noticeably since the Reformation period. First, the most powerful and compelling religious experience is 'unmediated'; it is an experience that believers have for themselves, rather than one that is reported to them. Second, for authenticity as a religious leader, it is necessary to have had this kind of compelling, first-hand experience. For example, to speak with authority as a leader of a Christian community, one must have had a personal experience of the Risen One. Third, hierarchical leadership is one model, but not the only model of leadership. Finally, leadership need not be limited on the basis of sex or other physical traits.

\section{What did the New Prophecy reclaim?}

The New Prophecy of Asia Minor (called 'Montanism' by its opponents-see Chapter 43 in this volume) was one example of a Christian movement that seems to have taken hold of these four lessons from Gnosticism, but without adopting the Gnostic context for them. Montanism appears on the scene in Asia Minor sometime during the third quarter of the second century. The movement originated in Phrygia, a region in the southwestern portion of the Roman province of Asia. ${ }^{2}$ Three initial leaders are known by name: Maximilla, Montanus, and Priscilla. All three were prophets who seem to have had ecstatic experiences during worship, and who also gave prophetic speeches in discursive language. Several of their oracles survive, but none in their original context. A few are recorded by Tertullian of North Africa, but most appear only as fragments reported by anti-Montanist writers in order to refute them.

Montanism arose as a 'renewal movement' within the church to combat at least some of the teachings of Gnosticism. Over against a denial of the full humanity of Christ and of the historical reality of the resurrection, the surviving oracles proclaim the reality of Christ's incarnation and affirm a Trinitarian view of the Godhead (McGinn-Moorer 1989: 312-4). They insist on the salvation of 'the little ones' (not just a 'Gnostic' elect), the importance of moral discipline in the Christian life, and the value of martyrdom as a share in the power of Christ. Both of these latter were viewed by libertarian Gnostics as pointless acts, since they had to do with the flesh rather than the spirit.

The New Prophecy often was linked by its opponents with Gnosticism, however, because of the prophetic and gender-inclusive leadership patterns noted above. Also, like the Gnostics, the leaders of the New Prophecy cherished 'unmediated' religious experience, for their leadership roles were based upon their prophetic gifts. Most scholars of Montanism view their leadership structure as more egalitarian than hierarchical, particularly given that leaders were selected based upon a charismatic gift. Their leadership consisted in the ability to share that gift of prophecy with the Montanist 


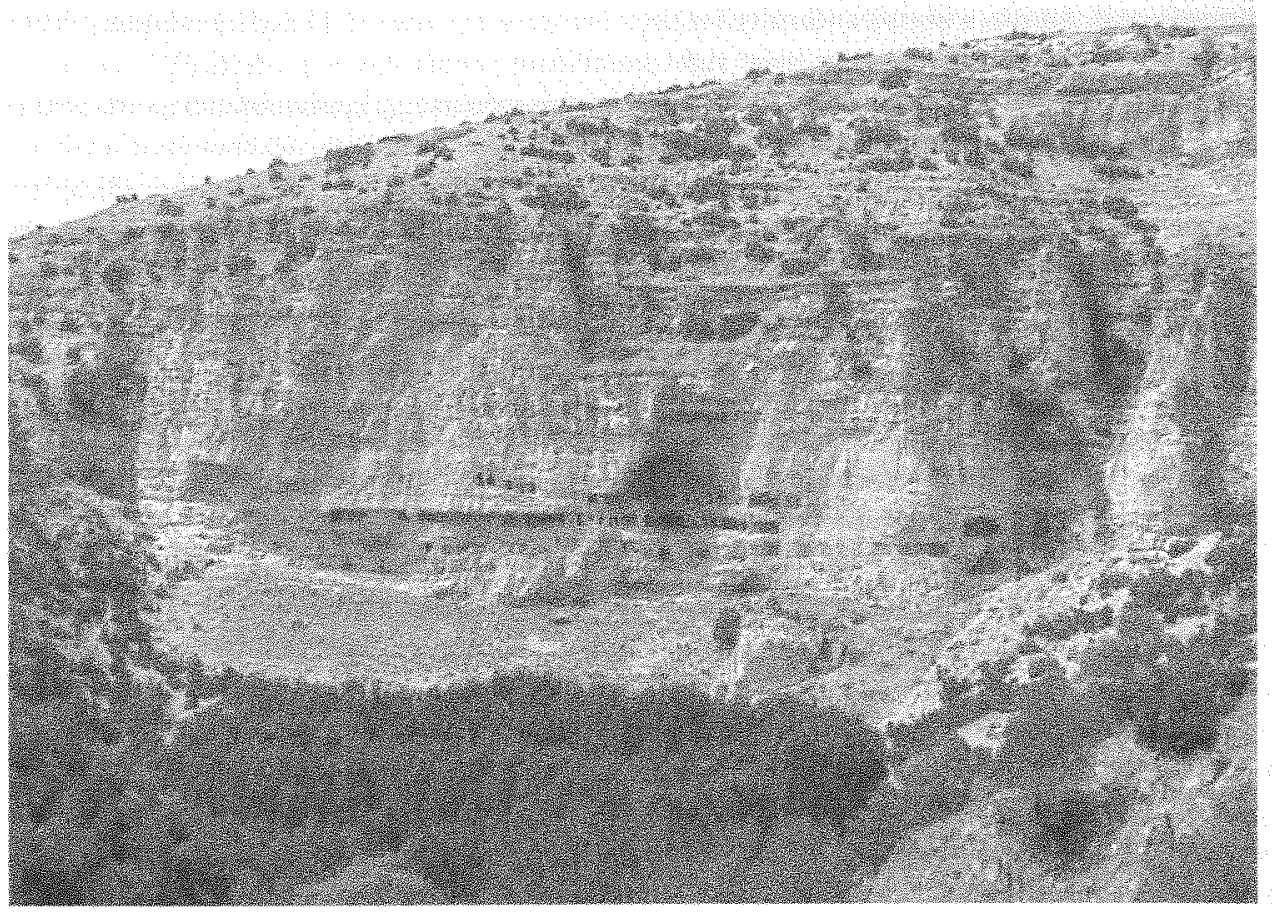

Figure 41.5 Rock-cut Byzantine monastery near Pepouza which may be the site of an ancient Montanist enclave; Photo Peter Lampe and Bill Tabbernee; for an enlarged view, see Figure 43.4, this volume

community, not on any kind of inherited rank. Two of the three prophets were women, which illustrates that sex was not a criterion for selection of Montanist leaders. Neither do other inherent physical traits appear to have been used as selection criteria. We do find that Maximilla and Priscill separated from their husbands, presumably to lead a celibate lifestyle, but this is a status choice rather than an inherent physical characteristic

The New Prophecy looks like a 'renewal movement' in its lively worship, and especially in it focus on the continuing revelation of God through prophetic speech and visions, precisely because this is not an innovation but a return to (or continuation of an earlier tradition. Many first- and second-century Christian texts speak of prophets, prophecy, preachers speaking under the influence of the Spirit of God, worship in the Spirit, and similar themes (see 1 Corinthians 11-14; Acts 2, 4, 9, etc.; Didache 10.7; 11.7). Clement of Rome (fl. 92-101) insists that his letter to Corinth is prompted by the Holy Spirit (First Epistle to the Corinthians 63.2); in the opening greeting of each of his letters, Ignatius of Antioch (35?-107) claims the title 'Theophorus' - God-bearer-because of his prophetic gifts (cf. his Epistle to the Philadelphians 7.2), and he encourages Polycarp of Smyrna (c. 70-156) to seek spiritual revelations (Epistle to Polycarp 2.2); the martyrs were known to have visions and revelations of Christ in their last hours (Martyrdom of Polycarp 2.2; 9.1), and even crowds of on-looker were said to see miraculous visions (Martyrdom of Polycarp 15.1-2). The Shepherd of Hermas is even full-blown second-century apocalypse, including visions and revelations. In such a context, the prophetic activity found in Montanism can certainly be no novelty. However, it can be a revival of prophecy and other manifestations of the Spirit in the face of a rising emphasis on an authoritative teaching tradition that is 'handed down' by word-of-mouth.

The New Prophecy may have been a threat to the 'orthodox' church not because of its novelty but precisely because it maintained or revived an older, prophetic tradition rather than giving way to the new hierarchical tradition of authoritative teachers. Montanist insistence on prophecy posed a similar threat as did Gnosticism because of its understanding of leadership as arising out of a specific and immediate religious experience-in this case, the experience of prophetic revelation. The charismatic nature of this experience did not lend itself to the kind of control which was sought by those who claimed the name 'orthodox.' Direct and new revelation could threaten the existing beliefs of the church, and certainly could not be controlled by human agents in the same way that a teaching tradition could be. In addition, the Montanists permitted women to lead prayer and worship, whereas the orthodox increasingly wanted to restrict these roles to influentral men.

\section{'Thus I refute the Manichees!'3}

Manichæism arose during the mid third century CE in Sassanid Persia (see Chapter 46 of this work) Founded by the prophet Mani (c. 216-276 CE), the doctrine of the sect drew from various religious sources in the east, including Zoroastrianism, Gnosticism, and the Elkasaite sect of Christianity, in which Mani himself was raised. Mani seems to have viewed himself as the fulfillment of the Johannine promise of 'another Paraclete' (John 14:16) and his revelation as the ultimate religion, which encompassed and completed all the preceding revelations from Jesus, the Buddha, and Zoroaster. Thus, Manicheism likely represents the first syncretistic universalist religion in human history.

Like Zoroastrianism before it, Manichxism addressed the theodicy question basic to monotheistic religions by adopting a dualistic worldview. Monotheistic religions envision one good, just, and allpowerful deity. However, this construction of the divine reality tends to shipwreck on the problem of Evil: if God is all-powerful, good, and just, then why do the good suffer and the evil prosper? Is God incapable of eliminating evil? Then God is not all-powerful. If God has the power but permit evil to flourish, then God is not all-good or just. Religious dualism, on the other hand, resolves this conundrum by positing two divine principles, one good and one evil.

The good God (the 'Father of Greatness'), in Mani's understanding, is not all-powerful, but rather is engaged in an ongoing conflict with primal evil ('the King of Darkness'). This conflict plays out in the heavenly realm as well as on earth, which is why even good people experience evil. Such dualist system provides a logical (if not very comforting) solution to the theodicy problem endemic to traditional monotheistic systems.

Such dualism on the divine level correlates to an ontological dualism whereby spiritual reality is viewed as good and material reality is viewed as evil. (As is common in dualistic systems, this dualism also is gendered, with the 'spiritual' realm viewed as masculine and the 'material' realm as 'feminine.') The material world comes about not as an act of free creation on the part of the one good God (as, for example, in Judaism) but rather as 'fallout' from the conflict between the two divine principles. That conflict continues to perdure in both the human and divine realms. The struggle between Good and Evil in the human realm reflects the same type of ongoing battle on the divine level.

Because material reality comprises the fallout from the conflict between Good and Evil, material objects are composed of 'evil' matter, but a spark of the Divine Good remains trapped within those material objects. The object of Manichæism is to liberate oneself from the grasp of materiality, and also to help liberate these divine sparks that are trapped in non-sentient material objects. All of life thereby becomes imbued with this divine task, so that even eating serves to liberate the divine sparks trapped in the fruits and vegetables consumed by the Manichæan elect. Eventually, the forces of good will be able to overthrow the forces of evil, but meanwhile the struggle rages on.

Manichæism spread to both east and west over the fourth through seventh centuries. In the west, it traversed the Roman empire and went so far as Spain, Dalmatia, and France; the medieval Cathar and Albigensians were the spiritual descendents of Manichæism. In the east, it became popular as far as China, where it lasted at least into the fourteenth century.

Augustine of Hippo (354-430 CE), the most famous of erstwhile Manichees, initially was attracted by their rigorous lifestyle of abstinence and their philosophical interpretations of scriptural texts, 
especially those pertaining to cosmology. Eventually, however, he became disenchanted with many aspects of Manichrism, including their neglect of scientific evidence when it disagreed with their cosmology and their identification of the God of the Old Testament with the Evil Deity.

Manichæism was never a Christian 'heresy' or even a dissenting movement; it began as and remained an independent, competing religious movement. Manichæism prompted Christians to reaffirm the goodness of the created realm, including human sexuality, and the dogma of the incar nation of the Divine Word in the fully human person of Jesus Christ. This notion of the Divine assuming 'fleshly' existence, abominable to Manichees and Gnostics alike, provided the Christian foundation for affirmation of the goodness of all creation and the value of the human body in the economy of salvation. It eventually provides the grounding for the entire sacramental system of Catholic Christianity, and the creation-centered spirituality of such figures as Francis of Assisi as well as contemporary eco-spirituality.

\section{Something old, something new, something borrowed: which is true?}

As can be seen from the preceding examples, the paradigm shift represented by this discussion of 'internal renewal and dissent' will have a profound impact on how we understand the development of 'the early Christian world.' Particularly in regard to doctrinal and institutional developments, the most significant difference which results from this change in assumptions-i.e., that there were a variety of early Christian models from the very beginning, rather than one, static reality-is that early Christians become much less alien than we thought. The history of early Christianity is a history of choices amid pluralism, not of a deus ex machina and an unthinking mob response. Some of these choices were later evaluated as orthodoxy, some as heresy, some as schism and some as another religion altogether. But such evaluative hindsight does not mean that any Christian chose heresy or schism. As today, believers followed their best lights, disagreed on significant issues, argued about them, and sometimes castigated, stereotyped, and marginalized those who disagreed with them. It remains important to learn what these early Christian groups borrowed from outsiders, revived from older traditions, or generated anew in light of their changing circumstances. Yet perhaps the most important thing we gain from this paradigm shift is that we now can learn how these diverse early Christian groups negotiated their differences, and what criteria they used to determine which of their old, new, and borrowed traditions would be retained for posterity. Whether we agree or disagree with their selections, whether we judge their decisions ultimately to be 'heresy' or 'orthodoxy, understanding the decision-making process is at least as important as recognizing its outcome.

Whether or not we know this history, contemporary Christians are not merely repeating but also continuing this process of negotiating difference. We can do so blindly, or we can do it intentionally, with openness to the lessons of these early Christian 'dissenters' and innovators. Perhaps we can arrive not at the divisive judgements of 'heresy' or 'orthodoxy,' but rather at a unity of purpose and understanding that might have been-and still might be.

\section{Notes}

1 The term 'Gnosticism' derives from the Greek word, gnosis (knowledge), and refers to a religious-philosophical movement of pre-Christian origins that influenced formative Judaism and early Christianity in the first two centuries CE. While there appear to have been several strands of Gnosticism with somewhat divergent cosmologies and theologies, generally speaking the movement was marked by a radically dualistic worldview, with material reality classified as evil and spiritual reality as good. The Gnostic ideal was to gain spiritual enlightenment and escape from the evils of material existence.

the site of the Montinist Pepouza may have recently been discovered.
3 A popular story of Thomas Aquinas $(1.225-1.274 \mathrm{CE})$ has him seated with guests at a banquet hosted by King Louis IX of France and interrupting the amiable conversation by slamming his fist on the table shouting, "thu I refute the Manichees:' Apparently, the table conversation was not as interesting to Thomas as the centuriesold library debate about this eastern alternative to Christianity.

4 See Chapter 11, Herbert Christian Merillat, The Gnostic Apostle Thomas: 'Tivin' of Jesus (1997), gnosis.org! Sec Clapter 11 , Hostic Society Library. 5 Ibid.

\section{Bibliography}

Achtemeier, P. J. (1987) The Quest for Unity in the New Testament Church. Philadelphia, PA: Fortress.

Barclay, J. (1995) 'Deviance and apostasy: Some applications of deviance theory to first-century Judaism and Christianity,' in Esler 1995: 114-27.

Bauer, W. (1934) Rechigliübigkeit und Ketzerei in ätesten Christentum. Tübingen, Germany. 2nd German ed. Strecker, G. (ed.), Tübingen: Mohr, 1964. English translation, Orthodoxy and Heresy in Earliest Christinnit), Kraft, R. A. and Krodel, G. (eds) Philadelphia, PA, 1971; London, 1972.

Bock, D. L. (2006) The Missing Gospets: Unearthing the Truth Behind Alternative Christianities. Nashville, TN Thomas Nelson.

Bonwetsch, G. N. (1881) Die Geschichte des Montanismus. Erlangen, Germany: Andreas Deicher. Dunn, J. D. G. (1977) Unity and Diversity in the New Testanent. London: SCM Press.

Esler, P. F. (ed.) (1995) Modelling Early Christianity: Social-Scientific Studies of the New Testament in Its Context. London and New York: Routledge.

Esler, P. F. (1998) Galatians. New' Testament Readings. London and New York: Routledge.

Henry, P. (1982) 'Why is contemporary scholarship so enamored of ancient heretics?,' in Livingstone, E. A. (ed.) Studia Patristica 17, no. 1. Oxford, UK and New York: Oxford University Press, 123-6.

Koester, H. (1982) Introduction to the New Testament. Two volumes. New York: Walter de Gruyter.

Lüdemann, G. (1996), Heretics: The Other Side of Early Christidnity. Lotisville, KY: Westminster John Knox. (ET from the German Ketzer. Die Andere Seite des frïhens Christentums. Stuttgart, Germany: Radius, 1995.) McGinn, S. E. (1994) 'The Acts of Thecla,' in Fiorenza, E. S. (ed.) Searching the Scriptures, Vol. 2: A Feminist Commentary. 2 vols. New York: Crossroad, 800-28.

McGinn-Moorer, S. E. (1989) The new prophecy of Asia Minor and the rise of ecclesiastical patriarchy in second century Pauline traditions. PhD dissertation. Evanston, IL: Northwestern University.

Pels, E. (1973) The Johannine Gospel in Gnostic Exegesis: Heracleon's Commentary on John. Nashville, TN: Abingdon.

Pagels, E. (1975) The Gnostic Paul: Gnostic Exegesis of the Pauline Letters. Philadelphia, PA: Fortress. Pagels, E. (1982) The Grostic Gospels. Harmondsworth, UK and New York: Penguin; repr. from Weiten

Nicolson, 1980.

Reumann, J. (1991) Variety and Unity in New Testament Thought. Oxford, UK: Oxford University Press.

Robinson, J. M. and Koester, H. (1971) Trajectories through Early Christianity. Philadelphia, PA: Fortress.

Tabbernee, W. and Lampe, P. (2008) Pepotza and Tymion: The Discovery and Archaeological Exploration of a Lost

Ancient City and an Imperial Estate. Berlin and New York: Watter de Gruyter.
Wilken Notre Dame Press, 1980

Zito, G. V. (1983) 'Toward a sociology of heresy,' Sociological Analysis 44: 123-30 